\section{The Present Condition of the Aborigines of Central Australia.}

I NFORMATION lately received in this country discloses an appalling condition of affairs among the aborigines of the interjor of Australia. The whole population is thoroughly polluted with disease, both tubercular and venereal, and the northeastern tribes are doomed. It is anticipated that another ten years will see the last of such interesting tribes as the Dieri, Yanntowanta, Ngameni, and Nauroworka. This is largely due to contact with the lower elements of European and immigrant Asiatic civilisation. Misdirected kindness, however, is also, to some extent, responsible. A liberal supply of Government blankets has been distributed among the tribes; they wear the blankets when working in the sun, and then, when thoroughly overheated, sleep on the ground; pneumonia follows as a natural consequence. Another cause of their disappearance is due to the difficulties attendant on food-supply. The game on which they subsist is killed off or driven away by the encroachment of civilisation. Distress from this cause has recently been aggravated by severe drought. The extent of the ravages arising from these various causes may be gauged by the fact that half a century ago it was estimated that there were 12,000 aborigines within 180 miles north and 200 miles east of Adelaide, and now there are not more than about 120 in that area. In the early eighties of last century Gason stated that if steps were not taken, multiplication of the aborigines would result in the disappearance of the European population, yet in this same area of which he wrote it is now estimated that at the outside there are not more than 2000 .

The deplorable condition of the aboriginal population was discovered owing to the fact that during the war a number of expeditions were sent out to Central and Northern Australia in connection with the search for minerals for use in munition work. Dr. Herbert Basedow, a Protector of Aborigines in the service of the South Australian Government, who was a member of several of these expeditions, was then brought into close contact with the tribes. On his return to Adelaide at the end of the war he endeavoured to arouse the public conscience by a meeting in the Town Hall, at which he gave an undisguised account of what he had seen. As a result $500 l$. has been subscribed, and an equal amount promised by the Government, for the provision of medical relief. This sum has enabled Dr. Basedow to get together a small relief party. His first expedition on this work followed the course of the Strzelecki to Innamincka, thence along the Cooper, across the boundary into Queensland. Recrossing the border, the party visited Cordillo, Cadelga, Ringamurra, and Birdsville, thence following the Diamantina to Hergott Springs. One of the severest droughts on record was raging at the time; the heat was terrific-the average temperature was $116^{\circ}-118^{\circ} \mathrm{F}$.and sand-storms blew for forty-eight hours at a time. No fewer than seven horses were abandoned exhausted along the route from Diamantina to Hergott Springs. The condition of the aborigines along the route is described by Dr. Basedow as "shocking." Dr. Basedow has recently started on another expedition. on which he proposes to proceed along the head of the Australian Bight as far as Eucla. along the Nullarboi Plains to Port Augusta, thence northwards to Oodnadatta, and across the boundary to the MrDonnel Rances.

Valuable as is such provision of medical relief as is possible by these expeditions, it is obviously only a temporary palliative. One of the most effective of the measures adopted for the assistance of the aborigines, whether directly under State protection or not, in the neighbouring State of Western Australia has been the establishment by the Government of a regular medical service. Further, while undesirable Europeans and Asiatics are permitted to mingle without control with the natives, it is inevitable that diseases will continue their ravages unchecked. A movement, which is receiving influential support, has been set on foot to induce the Government of South Australia to proclaim the north-west corner of the State, including the Musgrave, Mann, and Tomkinson Ranges, as an absolute reservation. It is hoped that it may also be possible to secure from the Commonwealth and the Western Australian Governments the proclamation of the adjoining ranges of the Northern Territory and Western Australia as strict reservations. This will probably be the last chance of preserving the Central Australian tribes from complete extinction.

E. N. Fallaize.

\section{University and Educational Intelligence.}

CAMBridge.--Dr. Shillington Scales has been appointed University lecturer in medical radiology and electrology, and Mr. F. Lavington, Emmanue College, Girdlers' lecturer in economics. Mr. J. Chadwick, Gonville and Caius College, has been elected to the Clerk Maxwell scholarship in experimental physics; Mr. H. F. Holden, St. John's College, to the Benn W. Levy research studentship in biochemistry; and Mr. A. J. Beamish, of Corpus Christi College, to the Wrenbury scholarship in economics.

The Marshall herbarium, comprising 23,000 sheets of British plants contained in dustproof oak cases, has been bequeathed to the University by the late Rev. E. S. Marshall, a keen and able field botanist, " unsurpassed as a collection of the critical flowering plants both in point of the number of interesting things he found and the care and industry he showed in selecting and pressing specimens of them."

EDINBURGH.-The foundation-stone of the new University buildings was laid by the King on Tuesday last, and the Queen accepted the honorary degree of I.I.D.

LiverPool.-The King, on the recommendation of the Chancellor and Council of the Duchy of Lancaster, has contributed Ioo guineas to the appeal fund.

ShefFIEld.-Dr. W. E. S. Turner has been appointed professor of glass technology, Mr. J. Husband professor of civil engineering, Dr. Mellanby professor of pharmacology, and Mr. R. E. Pleasance demonstrator in pathology.

By an inadvertence these appointments were given in NATURE of June 24 under the heading "Leeds."

Prof. F. Francis has been appointed Pro-ViceChancellor of the University of Bristol in succession to Prof. Lloyd Morgan, who is about to resign the office.

Dr. O. C. Bradley, principal of the Royal (Dick) Veterinary College, Edinburgh, has been elected president of the Royal College of Veterinary Surgeons in succession to Mr. J. McKinna.

A school of medicine, surgery, and dentistry in connection with the University of Rochester, New York, has received an endowment of $1,800,000 l$. from the U.S. General Education Baard and Mr. G. Eastman, of the Eastman Kodak Co. The contribution of the Board is I, ooo, oool., and that of Mr. Eastnan $800,000 l$. 